\title{
HUBUNGAN MOTIVASI KERJA DENGAN KINERJA KARYAWAN PADA PT KAO INDONESIA
}

\author{
Indra Jaya \\ Dosen Tetap Fakultas Ekonomi Universitas Pakuan \\ Surya Ningsih \\ Mahasiswa Fakultas Ekonomi Universitas Pakuan
}

\begin{abstract}
ABSTRAK
Motivasi mempunyai hubungan erat dan bagaimana perilaku seseorang dimulai, disokong, dikuatkan dan diarahkan. Oleh karena itu dasar untuk memotivasi karyawan antara lain adalah membuat suasana kerja yang dapat menimbulkan atau membuat karyawan dapat bertindak dan melakukan sesuatu. Pada dasarnya kinerja karyawan merupakan hasil proses yang kompleks, baik berasal dari diri pribadi karyawan tersebut (internal faktor) maupun upaya strategis dari perusahaan melalui seorang pemimpin, salah satu cara pengingkatan demi mencapai kinerja yang baik adalah dengan memberikan motivasi atau dorongan. Penelitian ini ditujukan untuk menjelaskan apakah ada hubungan motivasi kerja dengan kinerja karyawan pada perusahaan PT Kao Indonesia.Hasil analisis korelasi pearson product moment diperoleh koefisien korelasi sebesar 0,540 artinya motivasi kerja dengan kinerja karyawan memiliki hubungan yang sedang. Koefisien determinasi sebesar $29,16 \%$ artinya variasi kinerja karyawan dapat dijelaskan oleh motivasi kerja sebesar $29,16 \%$ dan sisanya $70,84 \%$ dijelaskan oleh faktor lain yang tidak diteliti. Hasil uji hipotesis korelasi dengan uji $\mathrm{t}$ menunjukkan $\mathrm{t}_{\text {hitung }}>\mathrm{t}_{\text {tabel }}(4,889>2,002)$ maka $\mathrm{H}_{0}$ ditolak artinya terdapat hubungan yang nyata antara motivasi kerja dengan kinerja karyawan.
\end{abstract}

Kata Kunci : Motivasi Kerja dan Kinerja Karyawan

\begin{abstract}
Motivation has a close relationship and how a person's behavior begins, supported, strengthened and redirected. Therefore the basis for motivating employees, among others, is to create a work atmosphere that can cause or make employees can act and do something. Basically the employee's performance is the result of a complex process, both derived from the employee's personal self (internal factors) as well as the strategic efforts of the company through a leader, one of the ways of enhancing the sake of achieving good performance is to provide motivation or encouragement. This study aimed to clarify whether there is a relationship work motivation and performance of employees at PT Kao Indonesia.Hasil analysis Pearson product moment correlation coefficient correlation of 0.540 means that work motivation and performance of employees have a relationship that was. Determination coefficient of $29.16 \%$ means that employee performance variation can be explained by the work motivation of $29.16 \%$ and the remaining $70.84 \%$ is explained by other factors not examined. Hypothesis test results correlated with $t$ test showed $t_{\text {count }}>t_{\text {table }}(4.889>2.002) \mathrm{HO}$ is rejected it means there is a real relationship between work motivation and employee performance.
\end{abstract}

Keywords: Motivation and Employee Performance

\section{Pendahuluan}

Keinginan manusia bersumber pada kebutuhan masing-masing yang meletakkan titik berat yang berlainan mengenai kebutuhan dan keinginannya. Apabila kebutuhan dan keinginan tersebut tidak dapat dicapai, manusia akan berusaha mencapainya dengan bekerja semaksimal mungkin untuk memenuhinya. Motivasi berhubungan erat dengan bagaimana perilaku itu 
dimulai, disokong, dikuatkan dan diarahkan. Oleh karena itu dasar untuk memotivasi karyawan antara lain adalah membuat suasana kerja yang dapat menimbulkan atau membuat karyawan dapat bertindak dan melakukan sesuatu.

Sedangkan dari pihak perusahaan persyaratan-persyaratan yang diminta semakin tinggi. Tenaga-tenaga yang mempunyai tingkat ketrampilan tinggi makin banyak diminta. Jelaslah bahwa hubungan timbal balik karyawan dan perusahaan menimbulkan perkembangan yang positif. Beberapa orang harus memainkan peran sebagai top manajer, middle manajer dan bawahan yang harus memainkan peran sesuai porsi dan tanggung jawabnya masing-masing. Setiap organisasi memiliki sistem kewenangan, status dan kekuasaan yang berbeda-beda. Sementara setiap anggota dalam perusahaan mempunyai beragam kebutuhan yang diharapkan dapat terpenuhi melalui organisasi. Pada dasarnya kinerja karyawan merupakan hasil proses yang kompleks, baik berasal dari diri pribadi karyawan tersebut (internal faktor) maupun upaya strategis dari perusahaan melalui seorang pemimpin, salah satu cara pengingkatan demi mencapai kinerja yang baik adalah dengan memberikan motivasi atau dorongan, yang mana aktivitas motivasi ini dapat mempengaruhi gerak langkah kesuksesan serta kinerja karyawan. Karyawan yang termotivasi tentunya akan berdampak pada meningkatnya antusiasme kolektif.

PT Kao Indonesia merupakan salah satu perusahaan yang bergerak di bidang consumer goods yang berkedudukan di Jakarta.Perusahaan ini berdiri sejak tahun 1985. Keberhasilan dalam melaksanakan tugas pokok dan fungsi di PT Kao Indonesia akan tergantung dari kinerja karyawannya. Dengan kinerja karyawan yang semakin baik atau meningkat, maka hasil yang mereka berikan akan semakin baik. Berdasarkan observasi peneliti menurunnya motivasi diindikasikan oleh tingginya tingkat absensi karyawan yang dapat dilihat berdasarkan grafik dibawah ini. 


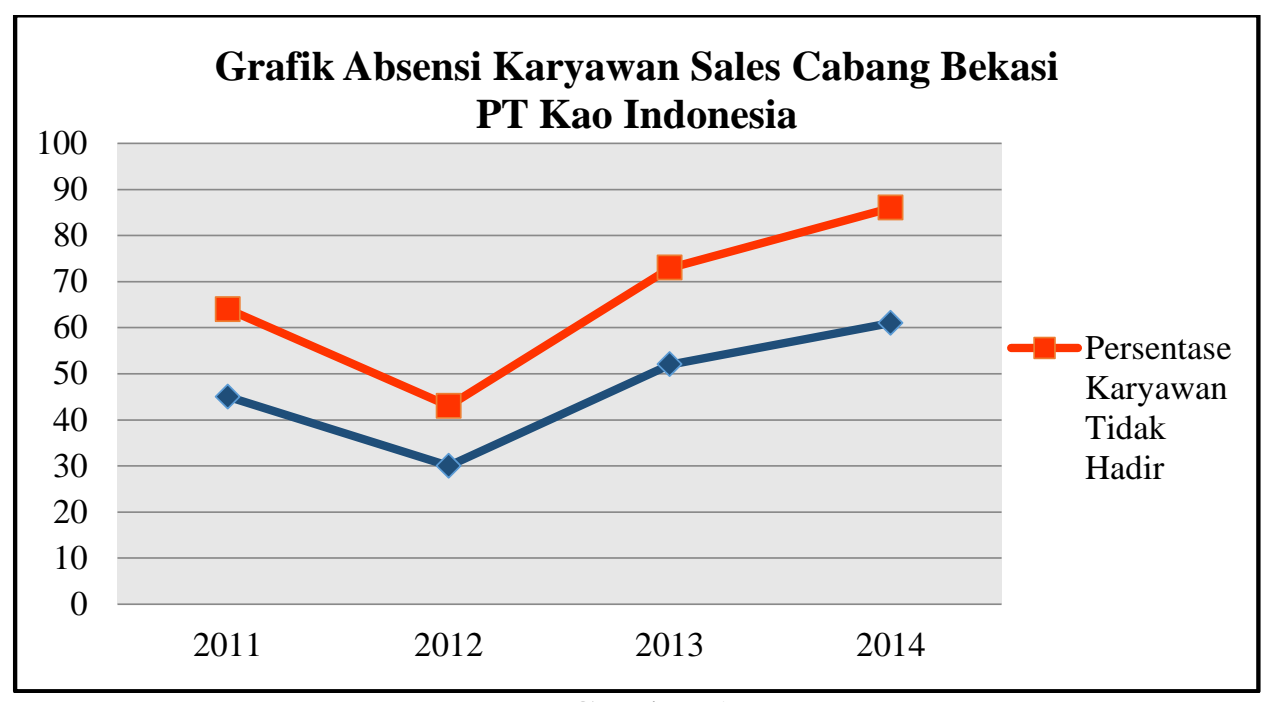

Gambar 1

Grafik Absensi Karyawan 2011-2014 PT Kao Indonesia

Grafik di atas menjelaskan bahwa telah terjadi peningkatan absensi karyawan dengan rata-rata setiap bulannya terdapat 4 orang yang tidak hadir untuk bekerja selama empat tahun terakhir tahun 2011 sampai 2014 dengan berbagai alasan. Hal ini semuanya termasuk dalam bagian motivasi kerja karyawan yang akhirnya membuat kinerja karyawan menurun. Dari latar belakang tersebut penulis tertarik untuk mengkaji lebih dalam dan melakukan penelitian tersebut.

Adapun tujuan dari penelitian ini adalah sebagai berikut:

1. Untuk mengetahui motivasi kerja karyawan pada PT Kao Indonesia.

2. Untuk mengetahui kinerja karyawan pada PT Kao Indonesia.

3. Untuk mengetahui hubungan motivasi kerja dengan kinerja karyawan pada perusahaan PT Kao.

\section{Landasan Teori}

Berkenaan dengan Motivasi Sunyoto (2013 : 1) menyatakan motivasi kerja adalah sebagai keadaan yang mendorong keinginan individu untuk melakukan kegiatan-kegiatan tertentu untuk mencapai keinginannya.
Motivasi yang ada pada seseorang merupakan kekuatan yang akan mewujudkan suatu perilaku dalam mencapai tujuankepuasan dirinya pada tipe kegiatan yang spesifik, dan arah tersebut positif dengan mengarah mendekati objek yang menjadi tujuan. Motivasi yang dikemukakan oleh Sutrisno (2015: 131) adalah sebagai berikut:

1. Kepuasan kerja;

2. Prestasi yang diraih;

3. Peluang untuk maju;

4. Pengakuan orang lain;

5. Kemungkinan pengembangan karir;

6. Tanggung jawab.

Berkaitan dengan kinerja, Fahmi (2013 : 2) menyatakan bahwa kinerja adalah gambaran mengenai tingkat pencapaian pelaksanaan suatu kegiatan/program/kebijaksanaan dalam mewujudkan sasaran, tujuan, misi dan visi organisasi yang tertuang dalam perumuan skema strategis (strategic planning) suatu organisasi. Menurut Bangun (2012 : 233), kinerja pegawai dapat diukur melalui:

1. Jumlah pekerjaan;

2. Kualitas pekerjaan; 
3. Ketepatan waktu;

4. Kehadiran;

5. Kemampuan kerjasama
Teori-teori tersebut didukung oleh beberapa penelitian terdahulu seperti di bawah ini:

Tabel 1

Penelitan Sebelumnya

\begin{tabular}{|c|c|c|c|c|}
\hline No & Peneliti & Variabel & Hasil Penelitian & $\begin{array}{c}\text { Persamaan/ } \\
\text { Perbedaan }\end{array}$ \\
\hline 1 & $\begin{array}{l}\text { Devi } \\
\text { Maulidiyawati, } \\
\text { Hubungan } \\
\text { motivasi kerja } \\
\text { dengan } \\
\text { produktivitas } \\
\text { karyawan divisi } \\
\text { produksi pada PT } \\
\text { Pupuk Kujang, } \\
\text { Cikampek, 2008 }\end{array}$ & $\begin{array}{l}\text { Motivasi } \\
\text { Kerja } \\
(\mathrm{X}) \\
\text { Produktivita } \\
\text { s (Y) }\end{array}$ & $\begin{array}{l}\text { Hasil uji koefisien korelasi } \\
\text { motivasi kerja memiliki } \\
\text { signifikansi terhadap } \\
\text { produktivitas karyawan sebesar } \\
0,000 \text { dan signifikansi penelitian } \\
\text { sebesar } 5 \% \text { atau } 0,05 \text {. Karena } \\
\text { signifikansi hitung < signifikansi } \\
\text { penelitian maka H0 ditolak, maka } \\
\text { terdapat hubungan yang signifikan } \\
\text { antara motivasi kerja dengan } \\
\text { produktivitas karyawan dengan } \\
\text { tingkat keeratan hubungan yang } \\
\text { kuat }(0,703)\end{array}$ & 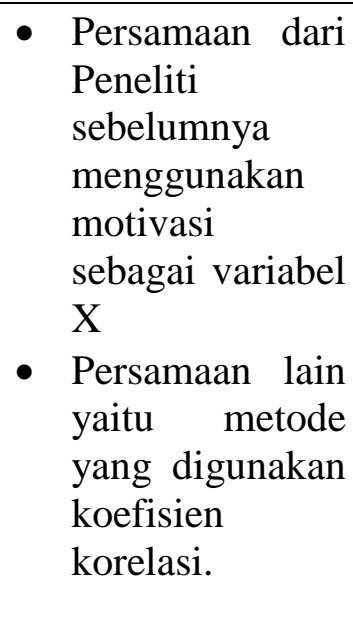 \\
\hline 2 & $\begin{array}{l}\text { Nazaruddin, } \\
\text { Hubungan } \\
\text { motivasi kerja } \\
\text { dengan kinerja } \\
\text { pegawai di Badan } \\
\text { Kepegawaian } \\
\text { Daerah dan Diklat } \\
\text { (BKDD) } \\
\text { Kabupaten } \\
\text { Maros, Makassar } \\
2012\end{array}$ & $\begin{array}{l}\text { Motivasi } \\
\text { Kerja (X) } \\
\text { Kinerja (Y) }\end{array}$ & $\begin{array}{l}\text { Berdasarkan uji korelasi antara } \\
\text { motivasi kerja dengan kinerja } \\
\text { pegawai,terbukti ada hubungan } \\
\text { yang kurang signifikan antara } \\
\text { motivasi kerja dengan kinerja } \\
\text { pegawai. Hal ini dapat dibuktikan } \\
\text { pada persamaan korelasi yang } \\
\text { memberikan hasil koefisien } \\
\text { korelasi (r) sebesar 0,274. Tanda } \\
\text { positif (+) yang diperlihatkan dari } \\
\text { koefisien korelasi (r) } \\
\text { menunjukkan bahwa meskipun } \\
\text { tingkat korelasinya rendah, namun } \\
\text { berhubungan positif yang artinya } \\
\text { jika variabel motivasi kerja } \\
\text { meningkat, maka akan diikuti oleh } \\
\text { variabel kinerja pegawai dan } \\
\text { sebaliknya. }\end{array}$ & $\begin{array}{l}\text { - Persamaan dari } \\
\text { Peneliti } \\
\text { sebelumnya } \\
\text { menggunakan } \\
\text { motivasi } \\
\text { sebagai variabel } \\
\text { X dan Kinerja } \\
\text { sebagai } \\
\text { Variabel Y. } \\
\text { - Persamaan } \\
\text { berikutnya } \\
\text { metode analisis } \\
\text { data yang } \\
\text { digunakan oleh } \\
\text { peneliti } \\
\text { sebelumnya } \\
\text { adalah koefisien } \\
\text { korelasi product } \\
\text { moment. }\end{array}$ \\
\hline 3 & $\begin{array}{l}\text { Aida Rahmita } \\
\text { Sari, Hubungan } \\
\text { Motivasi dan } \\
\text { Disiplin Kerja } \\
\text { Terhadap Kinerja } \\
\text { Guru di SMK } \\
\text { Muhammadiyah } 2 \\
\text { Yogyakarta, 2013 }\end{array}$ & $\begin{array}{l}\text { Motivasi } \\
\left(\mathrm{X}_{1}\right) \\
\text { Disiplin } \\
\text { Kerja }\left(\mathrm{X}_{2}\right) \\
\text { Kinerja }(\mathrm{Y})\end{array}$ & $\begin{array}{l}\text { Berdasarkan analisis dan } \\
\text { pembahasan dapat diperoleh: } 1 \text { ) } \\
\text { Terdapat hubungan positif antara } \\
\text { motivasi kerja guru dengan } \\
\text { kinerja guru di SMK } \\
\text { Muhammadiyah hal ini dibuktikan } \\
\text { dari nilai r hitung lebih besar dari } \\
\text { rtabel yaitu } 0,466>0,325 \text { dan nilai }\end{array}$ & $\begin{array}{l}\text { Persamaan dari } \\
\text { penelitian } \\
\text { sebelumnya } \\
\text { menggunakan } \\
\text { motivasi } \\
\text { sebagai variabel } \\
\text { X dan Kinerja } \\
\text { sebagai variabel }\end{array}$ \\
\hline
\end{tabular}




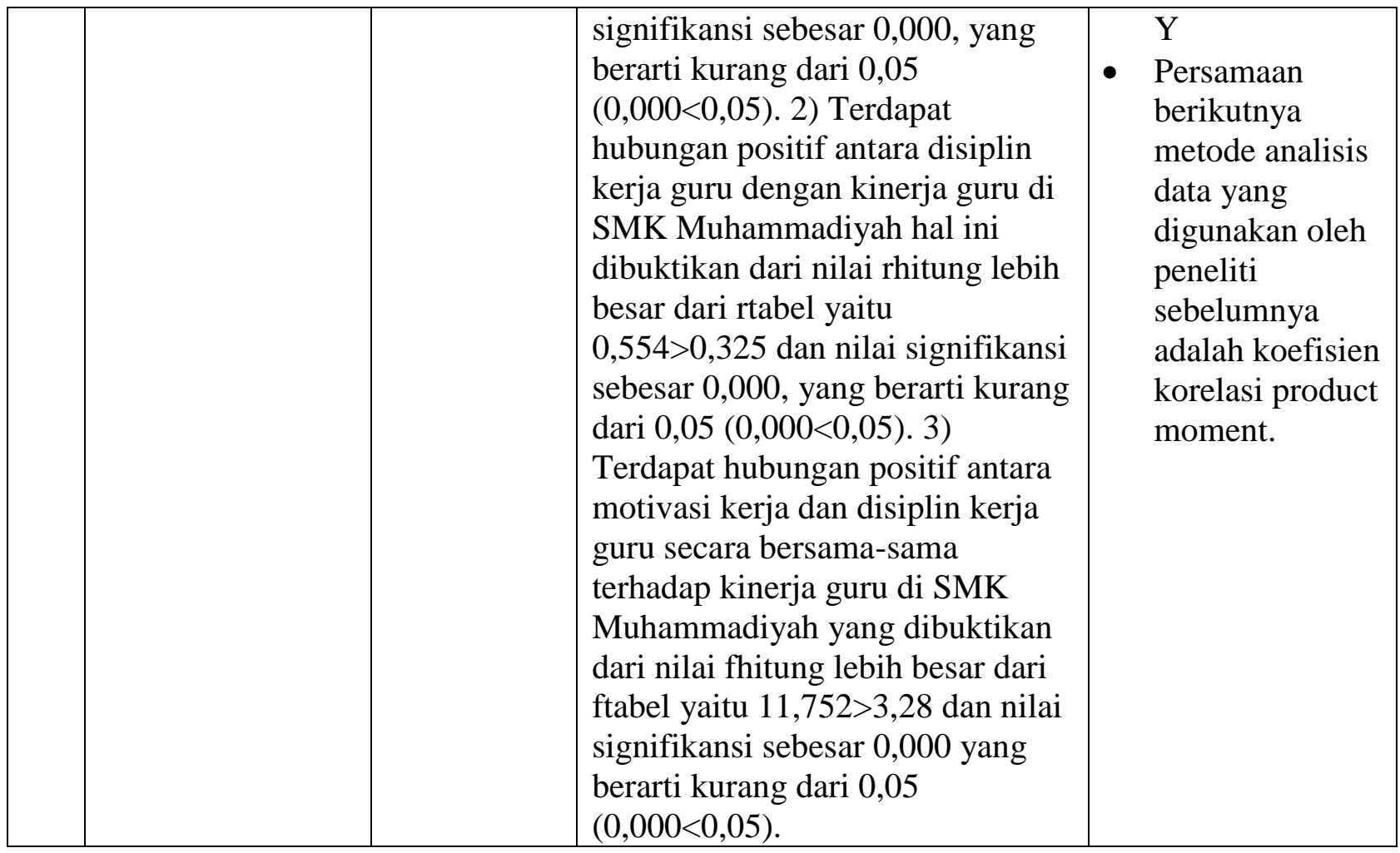

\section{Metodologi Penelitian}

Jenis penelitian yang digunakan adalah penelitian kuantitatif.Jenis penelitian ini penulis melakukan observasi langsung dengan cara survei, wawancara kepada pihak perusahaan, dan pengamatan secara langsung sehingga peneliti memperoleh data dari perusahaan dan akan diolah dengan alat statistik, untuk mengetahui mengenai hubungan motivasi kerja dengan kinerja karyawan. Dalam penelitian ini, penulis melakukan penelitian pada perusahaan PT Kao Indonesia yang berkedudukan di Jl. MT. Haryono Kav.39-40 Cikokol Pancoran Jakarta Selatan. Jenis data yang diteliti adalah data kuantitatif yang merupakan data primer karena data yang diperoleh dari hasil wawancara dengan menggunakan kuesioner atau berupa uraian/ penjelasan mengenai variabel yang diteliti.

Populasi dalam penelitian ini adalah seluruh karyawan bagian Sales PT kao Indonesia cabang Bekasi yang berjumlah 70 orang. Dengan tingkat signifikan $5 \%$ atau 0,05 dan tingkat keyakinan atau tingkat kepercayaan 95\%. Adapun rumus yang digunakan dalam penentuan jumlah sampel yang akan diteliti menggunakan metode slovin maka jumlah sampel dari populasi yang diambil untuk penelitian ini adalah sebanyak 60 orang.

Metode analisis data yang digunakan adalah, metode korelasional yaitu dengan korelasi pearson product moment, uji validitas, uji reliabilitas, koefisien determinasi dan uji hipotesis korelasi.

\section{Hasil dan Pembahasan}

Instrument pengukur dikatakan valid jika instrument tersebut mengukur apa yang seharusnya diukur. Dengan demikian kuesioner yang digunakan dapat berfungsi sebagai alat pengukur data yang akurat dan dipercaya. Uji validitas ini bisa dilakukan dengan membandingkan nilai $r_{\text {hitung }}$ dengan nilai $\mathrm{r}_{\text {tabel }}$ diambil dari output SPSS pada 
output "Correlation" kolom "pearson correlation-r hitung".

1. Uji Validitas Motivasi Kerja

Uji validitas dari variabel motivasi kerja dapat dilihat pada lampiran 1, 2, dan 3. Dari hasil uji validitas pada lampiran 3 untuk variabel motivasi kerja dapat disimpulkan bahwa item 10, 11, dan 14 dinyatakan tidak valid karena $r_{\text {hitung }}<r_{\text {tabel }}$, sedangkan item lainnya dinyatakan valid.

2. Uji Validitas Item Kinerja
Dari hasil uji validitas untuk variabel kinerja pada lampiran 4, 5 dan 6 dapat disimpulkan bahwa item 10 dan 13 dinyatakan tidak valid karena $r_{\text {hitung }}<r_{\text {tabel }}$, sedangkan item lainnya dinyatakan valid.

3. Uji Reliabilitas Item Motivasi Kerja Sebagaimana hasil yang dapat dilihat pada lampiran 7 bahwa 15 item untuk pertanyaan motivasi kerja dinyatakan reliable dengan cronchbach alpha 0,858.

Tabel 2

Case Processing Summary

\begin{tabular}{|c|r|r|}
\hline & \multicolumn{1}{|c|}{$\mathrm{N}$} & \multicolumn{1}{c|}{$\%$} \\
\hline \multicolumn{1}{|c|}{ Valid } & 20 & 100.0 \\
Cases Excluded & 0 & .0 \\
a Total & 20 & 100.0 \\
\hline
\end{tabular}

Tabel 3

Reliability Statistics

\begin{tabular}{|r|r|}
\hline $\begin{array}{c}\text { Cronbach's } \\
\text { Alpha }\end{array}$ & $\begin{array}{c}\text { N of } \\
\text { Items }\end{array}$ \\
\hline .858 & 15 \\
\hline
\end{tabular}

Dari hasil output diatas case processing summary menjelaskan bahwa jumlah data yang valid untuk diproses sebanyak 15 item dengan persentase $100 \%$ maka tidak ada item yang dikeluarkan dan realibility statistic menunjukkan bahwa cronbach alpha 0,858 ini artinya dapat disimpulkan instrument penelitian telah reliable atau valid.

4. Uji Reliabilitas Item Kinerja

Pada lampiran 8 sebanyak 13 item atas hasil uji reliabilitas kinerja dinyatakan reliable karena sehingga pertanyaan-pertanyaan tersebut dapat digunakan untuk pembahasan berikutnya.

Tabel 4

Case Processing Summary

\begin{tabular}{|cc|c|c|}
\hline & & $\mathrm{N}$ & $\%$ \\
\hline \multirow{4}{*}{ Cases } & Valid & 20 & 100.0 \\
& Excluded $^{\mathrm{a}}$ & 0 & .0 \\
& Total & 20 & 100.0 \\
\hline
\end{tabular}




\section{Tabel 5 \\ Reliability Statistics}

\begin{tabular}{|c|c|}
\hline $\begin{array}{c}\text { Cronbach's } \\
\text { Alpha }\end{array}$ & $\begin{array}{c}\mathrm{N} \text { of } \\
\text { Items }\end{array}$ \\
\hline .894 & 13 \\
\hline
\end{tabular}

Dari hasil output di atas case processing summary menjelaskan bahwa jumlah data yang valid untuk diproses sebanyak 13 item dengan persentase $100 \%$ maka tidak ada item yang dikeluarkan dan realibility statistic menunjukkan bahwa cronbach alpha 0,894 ini artinya dapat disimpulkan instrument penelitian telah reliable atau valid.
Untuk mengetahui dan membuktikan bagaimana hubungan antara motivasi kerja denga kinerja karyawan pada bagian sales PT Kao Indonesia, maka dilakukan dengan analisis korelasi pearson product moment dengan bantuan alat statistik SPSS.

Tabel 6

Correlations

\begin{tabular}{|rl|r|r|}
\hline & & $\begin{array}{c}\text { Motiva } \\
\text { si } \\
\text { Kerja }\end{array}$ & Kinerja \\
\hline $\begin{array}{l}\text { Motivas } \\
\text { i Kerja }\end{array}$ & $\begin{array}{l}\text { Pearson } \\
\text { Correlation } \\
\text { Sig. (2- } \\
\text { tailed) } \\
\text { N } \\
\text { Pearson } \\
\text { Correlation } \\
\text { Sig. (2- } \\
\text { tailed) }\end{array}$ & $.540^{* *}$ & $.540^{* *}$ \\
Kinerja & .000 & .000 \\
& & 60 & \\
& & 60 & 60 \\
\hline
\end{tabular}

**. Correlation is significant at the 0.01

level (2-tailed).

Sumber: data diolah 2016

Dari tabel di atas diketahui bahwa hubungan kedua variabel yaitu motivasi kerja dengan kinerja adalah sebesar 0,540 dengan tingkat hubungan yang sedang, karena angka signifikansi sebesar 0,000 dengan jumlah sampel (N) yang digunakan sebanyak 60 responden. Untuk melihat arah korelasi antara dua variabel tersebut dilihat dengan angka 0,540 karena angka tersebut hasilnya positif maka korelasi kedua variabel bersifat searah atau berbanding lurus. 
Untuk tanda dua bintang ini mempunyai arti bahwa signifikan pada angka signifikansi sebesar 0,01 dan mempunyai kemungkinan dua arah (2-tailed). Kesimpulan dari analisis di atas adalah jika motivasi kerja yang diberikan perusahaan tinggi maka tingkat kinerja yang dihasilkan oleh karyawan akan semakin meningkat pula.

Hasil dari analisis koefisien determinasi tersebut menunjukkan bahwa motivasi kerja dapat mempengaruhi kinerja sebesar $29,16 \%$, sedangkan sisanya sebesar 70,84\% dipengaruhi oleh faktor lain yang tidak diteliti dalam penelitian ini.

Dengan melihat signifikansi $5 \%$ atau 0,05 dan df 58 maka nilai yang diperoleh dari $t_{\text {tabel }}$ adalah 2,002 hasil ini nantinya yang akan dibandingkan dengan hasil dari $t_{\text {hitung. }}$

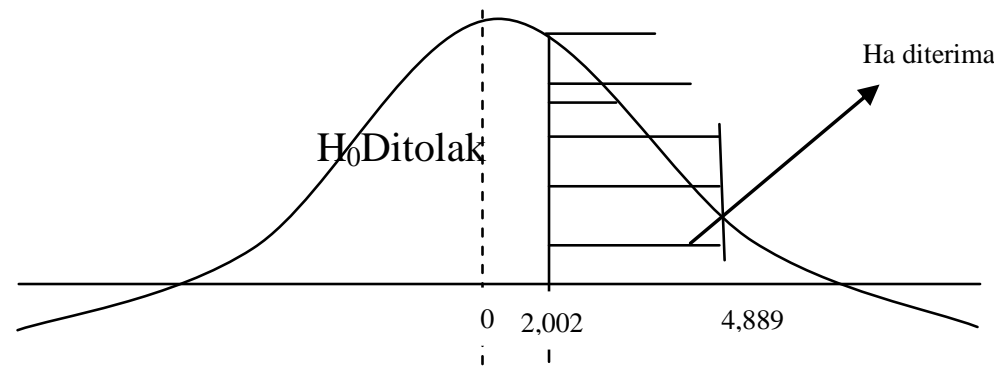

Gambar 2

Kurva Hasil Pengujian Hipotesis Korelasi

Berdasarkan Kurva hasil pengujian hipotesis korelasi di atas terlihat bahwa $\mathrm{t}_{\text {hitung }}$ sebesar 4,889 angka ini lebih besar dari $t_{\text {tabel }}$ yang sebelumnya telah diketahui yaitu 2,002 sehingga $\mathrm{H}_{0}$ ditolak dan $\mathrm{H}_{\mathrm{a}}$ diterima. Dengan angka tersebut menunjukkan bahwa terdapat hubungan yang positif antara motivasi kerja dengan kinerja karyawan.

\section{Penutup}

Dari hasil pembahasan pada bab sebelumnya, maka penulis dapat menarik simpulan bahwa dengan jumlah responden sebanyak 60 orang kemudian diketahui bahwa total responden yang memiliki skor rata-rata di atas sebanyak 20 orang dan nilai sebaran interval motivasi kerja yang dihasilkan adalah $33,33 \%$ yang berada pada interval nilai 30 sampai 49 dengan keterangan kurang baik sehingga peneliti dapat mengambil simpulan bahwa motivasi kerja karyawan pada bagian sales di PT Kao Indonesia dinyatakan masih kurang baik. Skor dari hasil jawaban pertanyaan kuesioner mengenai kinerja sebanyak 60 responden dan diperoleh sebanyak 23 respnden dengan skor total diatas rata-rata sehingga didapat dengan nilai sebaran interval sebesar 38,33\%. Hasil tersebut membuktikan bahwa kinerja pada bagian sales PT Kao Indonesia masih kurang baik. Terdapat hubungan yang signifikan antara motivasi kerja dengan kinerja pada PT Kao Indonesia khususnya pada karyawan bagian sales dapat dilihat dari hasil analisis berikut ini: a) Hasil analisis korelasi pearson product moment, diperoleh $\mathrm{r}^{\mathrm{s}}$ sebesar 0,540. Artinya adalah motivasi kerja dengan kinerja memiliki hubungan yang sedang dan dua 
arah dan motivasi kerja yang diberikan perusahaan tinggi maka tingkat kinerja yang dihasilkan oleh karyawan akan semakin meningkat. b) Hasil dari analisis koefisien determinasi diperoleh bahwa motivasi kerja dapat mempengaruhi kinerja sebesar $29,16 \%$, sedangkan sisanya sebesar 70,84\% dipengaruhi oleh faktor lain di luar motivasi kerja misalnya lingkungan perusahaan. Terakhir, hasil dari uji hipotesis koefisien korelasi menunjukkan nilai dari $t_{\text {hitung }}>t_{\text {tabel }}$ $(4,889>2,002)$ ini berarti $\mathrm{H}_{0}$ ditolak dan $\mathrm{H}_{\mathrm{a}}$ diterima, artinya adalah terdapat hubungan yang nyata positif antara variabel $X$ (Motivasi Kerja) dengan variabel Y (Kinerja).

\section{DAFTAR PUSTAKA}

Badeni (2014), Kepemimpinan \& Perilaku Organisasi. Penerbit Alfabeta. Bandung

Bangun, Wilson (2012), Manajemen Sumber Daya Manusia. Erlangga, Jakarta.

Bernardin, H.J, Russel J.E.A (1993), Human Resource Management. Singapore. Mc Graw Hill, Inc.

Byars, Llyod L, \& Rue, Leslie W (1997),

Human Resource Management. Fifth Editon. Irwin.

Dessler, Gary (2011), Human Resource Management Thirteenth Edition. New Jersey. Pearson Prentice Hall. Fahmi, Irham (2013), Manajemen Kinerja Teori dan Aplikasi. Penerbit Alfabeta. Bandung.

H. Moh. Pabundu Tika (2014), Budaya Organisasi dan Peningkatan Kinerja Perusahan. Bumi Aksara. Jakarta.

Mangkunegara, A.A. Anwar Prabu (2013), Manajemen Sumber Daya Manusia Perusahaan. PT Remaja Rosdakarya, Bandung.
McCormick, J Ernest (1985), Industrial Psychology. New York. Prentice hall, Inc.

Noor, Juliansyah (2013), Penelitian Ilmu Manajemen. Kencana Predana Media Grup. Jakarta

Priansa, Doni Juni (2014), Perencanaandan Pengembangan SDM. Alfabeta. Bandung.

Robbins, Sthephen P., and Merry Coulter (2013), Management. Elevent Edition, Pearson Education Limited, England.

Siagian, Sondang P. (2012), Teori Motivasi dan Aplikasinya. PT Rineka Cipta, Jakarta.

Sujanto, Bedjo. (2007), Manajemen Pendidikan Berbasis Sekolah: Model Pengelolaan Sekolah di Era Otonomi Daerah. CV Agung Seto. Jakarta

Sugiyono (2011), Metode Penelitian Kuantitatif, Kualitatif, dan $R \& D$, Penerbit Alfabeta. Bandung

Sugiyono (2014), Statistika Untuk Penelitian, Penerbit Alfabeta. Bandung.

Suwatno.dan Priansa, Junni, Donni (2014), Manajemen SDM dalam Organisasi Public dan Bisnis. Alfabeta. Bandung.

Sunyoto, Danang (2015), Teori Perilaku Keorganisasian. PT Buku Seru, Yogyakarta.

Sutrisno, Edy. (2012), Manajemen Sumber Daya Manusia. Kencana Prenadamedia Grup. Jakarta.

Thoha, Miftah. (2011). Perilaku Organisasi Konsep Dasar dan Aplikasinya. PT Rajagrafindo Persada. Jakarta.

V. Wiratna, Sujarweni (2014), Metodologi Penelitian. Pustaka Baru Press. Yogyakarta

Yani, M. (2012), Manajemen Sumber Daya Manusia. MitraWacana Media. Jakarta.

Makalah Seminar dan Skripsi 
Devi Maulidiyawati. (2008). Hubungan

Motivasi Kerja Dengan

Produktivitas Karyawan Divisi Produksi Pada PT Pupuk Kujang. Skripsi Program Strata Satu Universitas Islam Bandung.P

Nazaruddin (2012). Hubungan Motivasi Kerja Dengan Kinerja Pegawai di Badan Usaha Kepegawaian Daerah Dan Diklat Kabupaten
Maros Yogyakarta. Skripsi Program Strata Satu Universitas Hasanuddin. Makassar

Aida Rahmita Sari. (2013). Hubungan Motivasi dan Disiplin Kerja Dengan Kinerja Guru SMK Muhammadiyah Yogyakarta. Skripsi Program Strata Satu Universitas Negeri Yogyakarta. 